\title{
Алла Юрченко
}

Київський національний університет імені Тараса Шевченка

\section{Роль громадських організацій у формуванні та імплементації антикорупційної реформи в Україні}

У статті викладено результати аналізу дослідження ролі інститутів громадянського суспільства у формуванні та імплементації антикорупційної реформи в Україні. Розглянуто успішний досвід та механізми участі громадських організацій у формуванні нових антикорупційних інститутів, антикорупційних заходах, адвокації антикорупційної реформи та ухвалення нового антикорупційного законодавства в Україні. Особливу увагу зосереджено на ролі місцевих громадських організацій та їх взаємодії в заходах із запобігання політичній корупції з органами місцевого самоврядування та державними органами. Розглянуті основні напрямки діяльності громадських організацій у частині протидії корупції та загальні проблеми, що виникають під час антикорупційної роботи таких організацій.

Ключові слова: корупція, політична корупчія, громадська організація, антикорупиійна реформа, інститут

\section{The role of public organizations in the formation and implementation of anti- corruption reform in Ukraine}

\section{Alla Yurchenko, Taras Shevchenko National University of Kyiv}

The article presents the results of the analysis of the study of the role of civil society institutions in the formation and implementation of anti-corruption reform in Ukraine. The successful experience and mechanisms of participation of public organizations in the formation of new anti-corruption institutions, anti-corruption measures, advocacy of anti-corruption reform and the adoption of new anti-corruption legislation in Ukraine are considered. Particular attention is paid to the role of local NGOs and their interaction in measures to prevent political corruption with local governments and state bodies. The main directions of activity of public organizations in the part of counteraction to corruption and the general problems arising during anti-corruption work of such organizations are considered.

Keywords: corruption, political corruption, public organization, anti-corruption reform, institute

$\prod_{\text {країн1 }}$ ослідження значення та впливу громадських організацій в антикорупційному порядку денному в Україн1 $є$ актуальним у теоретичному та практичному вимірах. Особливу увагу слід звернути на роль громадських організацій на місцевому та регіональному рівні, оскільки головними критеріями успішності або ж визначення тих чи інших проблемних зон реалізації антикорупційної реформи є рівень iii імплементації на місцевому та регіональному рівнях, особливо в умовах децентралізації. Основу тезової доповіді складають матеріали наукових досліджень, моніторингові звіти міжнародних та провідних антикорупційних організацій, а також емпіричних досліджень.

Варто відзначити те, що головною рушійною силою проведення глобальної антикорупційної реформи в Україні після Революції Гідності стали громадські організації 142 та громадськість загалом. У таких умовах представники громадських організацій разом 3 представниками міжнародних організацій, міжнародних партнерів взяли відповідальність за створення нового антикорупційного порядку денного для України, який відповідав запитам суспільства. Це стало прецедентом ефективної участі громадськості у формуванні антикорупційної політики.

Так, в аналітичні статті «Громадянське суспільство проти корупції в Україні: способи впливу» (підготовлена в межах дослідження «Вплив громадянського суспільства на впровадження антикорупційних реформ в Україні», що реалізовувалося 1,5 року у співпраці з Лейденським університетом (Нідерланди) та представниками Міждисциплінарного науково-освітнього центру протидії корупції НаУКМА ) зазначено, що громадські організації, що працюють у сфері боротьби 3 корупцією, часто відіграють центральну роль 
в ініціюванні та просуванні антикорупційних реформ в Україні. Організації громадянського суспільства визнані суб'єктами, що можуть відігравати важливу роль у боротьбі з корупцією. Зокрема, у статті Конвенції Організації Об'єднаних Націй проти корупції зазначено, що «[к]ожна Держава-учасниця вживає належних заходів, у межах своїх можливостей i згідно з основоположними принципами свого внутрішнього права, для сприяння активній участі окремих осіб і груп за межами державного сектора, таких як громадянське суспільство, неурядові організації та організації, що функціонують на базі громад, у запобіганні корупції й боротьбі $з$ нею та для поглиблення розуміння суспільством факту існування, причин і небезпечного характеру корупції, а також загроз, що створюються нею» (Про запобігання корупції, 2014).

Організації громадянського суспільства на відмінну від державних структур чи/або міжнародних організацій можуть володіти більшою інформацією щодо місцевої корупції, мають стійкий зв'язок $з$ місцевим населенням, можуть мати різних форм довіру та авторитет. Представники громадських організацій переважно намагаються сформувати стійкі зв'язки на місцевому рівні 3 пересічними громадянами задля можливості повідомити/викрити корупційні дії тих чи інших високопосадовців, представників влади або керівників державних підприємств. Крім цього здійснюється активна робота в напрямку просвітництва, проведення освітніх заходів, тренінгів, семінарів, аналітичної роботи та поширення інформації щодо необхідності повідомлення про факти корупції, надання консультативної інформації щодо захисту викривачів, поширення інформації щодо позитивних прикладів протидії корупції.

При аналізі діяльності антикорупційних організацій та їх впливу на розвиток антикорупційної реформи в Україні, варто зазначити неабияку участь громадянського суспільства у безпосередньому інституційному оформленні нових антикорупційних державних органів. Так, наприклад, Національне антикорупційне бюро України стало першим органом, який долучив до роботи громадські організації задля підтримки у створенні та запуску роботи органу, кадрового відбору та проведення співбесід.

Виходячи 3 положень Закону України «Про запобігання корупції», взаємодія влади та громадськості в процесі запобігання корупції має розвиватися у трьох напрямах: 1) надання пропозицій органам влади за результатами проведення досліджень/ громадської антикорупційної експертизи; 2) надання пропозицій щодо вдосконалення наявного антикорупційного законодавства; 3) вплив громадських організацій на формування державної антикорупційної політики. Громадськість має право подавати за результатами експертизи нормативно-правових актів пропозиції до відповідних органів влади (Про громадські об'єднання, 2013).

Проте варто відзначити, що рівень сприйняття та врахування пропозицій антикорупційних організацій серед представників влади досить низький. Опоненти, до яких іноді належать представники уряду, часто дискредитують діяльність організацій громадянського суспільства у таких країнах через їхню залежність від зовнішнього фінансування та відсутність сильної бази підтримки (Білецький, 2019).

Сьогодні діяльність громадських антикорупційних організацій формально підпадає під шість категорій: моніторинг та звітування, підвищення обізнаності, адвокація, акції прямої дії, нарощування експертних компетенцій та співурядування (Моніторинговий звіт «Вплив громадських організацій на впровадження антикорупційних реформ в регіонах України» (ACREC, НАУКМА, 2019, c. 5-11).

Також громадські організації у сфері протидії корупції активно долучаються для формування та реалізації державної антикорупційної політики шляхом участі у громадських радах, консультативно-дорадчих органах та комісіях. Яскравим прикладом може слугувати Рада громадського контролю Національного антикорупційного бюро України, яка формується з делегованих представників громадських антикорупційних організацій щорічно шляхом рейтингового інтернет-голосування та покликана здійснювати громадський контроль за діяльністю органу. 
Представники громадських антикоруп- органів, протидії політичній корупції та коційних організацій вказують на складність у рупції загалом дозволяє говорити про те, що

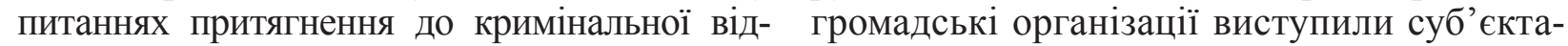
повідальності чиновників високого рангу та ми протидії корупції в Україні після Ревополітиків вищих щаблів влади. Такий підхід люції Гідності. Проте відсутність широких формує зниження рівня довіри населення до повноважень громадськості, постійний опір діяльності антикорупційних органів та антико- 3 боку влади, відсутність політичної волі, рупційних громадських організацій, зокрема. брак підтримки з боку населення, а також

Отже, аналіз діяльності антикорупцій- проблеми інституційного розвитку самих них організацій та оцінка впливу представ- громадських організацій призводить до ників громадянського суспільства на про- зменшення можливостей впливу та зниженцес інституціоналізації антикорупційних ня антикорупційного активізму.

\section{БІБЛІОГРАФІЧНІ ПОСИЛАННЯ}

Білецький, А. В. (2017). Досвід участі громадськості у заходах щодо запобігання корупційної злочинності в Україні. Проблеми законності, 136 (17), 225-235.

Моніторинговий звіт «Вплив громадських організацій на впровадження антикорупційних реформ в регіонах України» (АCREC, НАУКМА). (2019). Відновлено з https://acrec.org.ua/wp-content/uploads/2019/12/zvit210x210-1e.pdf

Про громадські об’єднання. № 2572-VI. (2013). Відомості Верховної Ради України, 1, ст. 1.

Про запобігання корупції. № 1700-VII. (2014). Відомості Верховної Ради України, 49, ст. 2056. 